\title{
The Ironbridge
}

\section{An ASM Historical Landmark}

Received: 6 August 2012

(C) Springer Science+Business Media, LLC and ASM International 2012

ASM's Historical Landmark award was established in 1971 with the aim of preserving metallurgical heritage and increasing awareness of pioneering milestones of metalworking technology. The scope of the award was expanded to include man's greatest metalworking achievements from around the world. In 1984, the first sites outside North America were honored. One of these is the Ironbridge in Telford, Shropshire, England.

The Industrial Revolution transformed Great Britain into a world power. The beginning of that revolution is best symbolized by a simple, single-span bridge over the River Severn in the town of Telford. To the modern eye accustomed to longer, more grandiose spans, the Ironbridge is not an impressive structure, but it was a major innovation when it was built in 1779. It was the world's first Iron bridge.

Were it not for the technology developed by the ironmakers of over 200 years ago, which make the Ironbridge possible, the modern bridges upon which we stand, as well as skyscrapers and other modern buildings, would not be possible.

That technology was first developed in Coalbrookdale, only a few miles away from the Ironbridge. In 1708, a charcoal blast furnace dating back to the 1630s was taken over by Abraham Darby, a Quaker ironmaster.

At that time, England was experiencing an energy crisis because of a shortage of its traditional fuel, charcoal. Mr. Darby experimented successfully with using coke in the smelting of iron ore, and iron production in England jumped as a result of this new process.

Within the next few decades, iron from the area was being used to build boats, buildings, and machinery of all types. In the words of Thomas Carlyle, British industry had "burst forth into cotton-spinning, cloth-cropping, ironforging, steam-engining, railwaying, commercing, and careering towards all the winds of heaven." The Severn became the second busiest river in Europe.

It would be several decades later, however, before an iron strong enough for the demands of a bridge was developed. Such an iron was developed in Coalbrookdale, and, under the technical direction of Abraham Darby III, the Ironbridge was erected.

Despite these achievements, iron manufacturing in the Telford area declined by the middle of the nineteenth century, moving to other areas of Great Britain where raw materials were more accessible.

The foundries were abandoned and the Ironbridge was scheduled for demolition until, in 1967, the Ironbridge Gorge Museum Trust was founded to preserve these monuments to the birth of industry.

Dedicated to conserving the birthplace of the Industrial Revolution and interpreting its remains in the six square miles of the Ironbridge Gorge, the Ironbridge Gorge Museum Trust is an independent education charity. Museum staff manages 35 historic sites, ten of which are museums. These ten museums receive more than 550,000 visitors annually.

At the Coalbrookdale Museum of Iron, visitors may explore the site and the remains of the water-powered blast furnace where Abraham Darby I perfected the smelting of iron with coke instead of charcoal. This was the secret that helped make iron the essential material of the Industrial Resolution. In the Great Warehouse, models, films, and original artifacts illustrate the revolutionary techniques that made Coalbrookdale the most famous ironworks in the world.

The Blists Hill Victorian Town transports visitors back to a period when this part of Shropshire was ruled by coal 


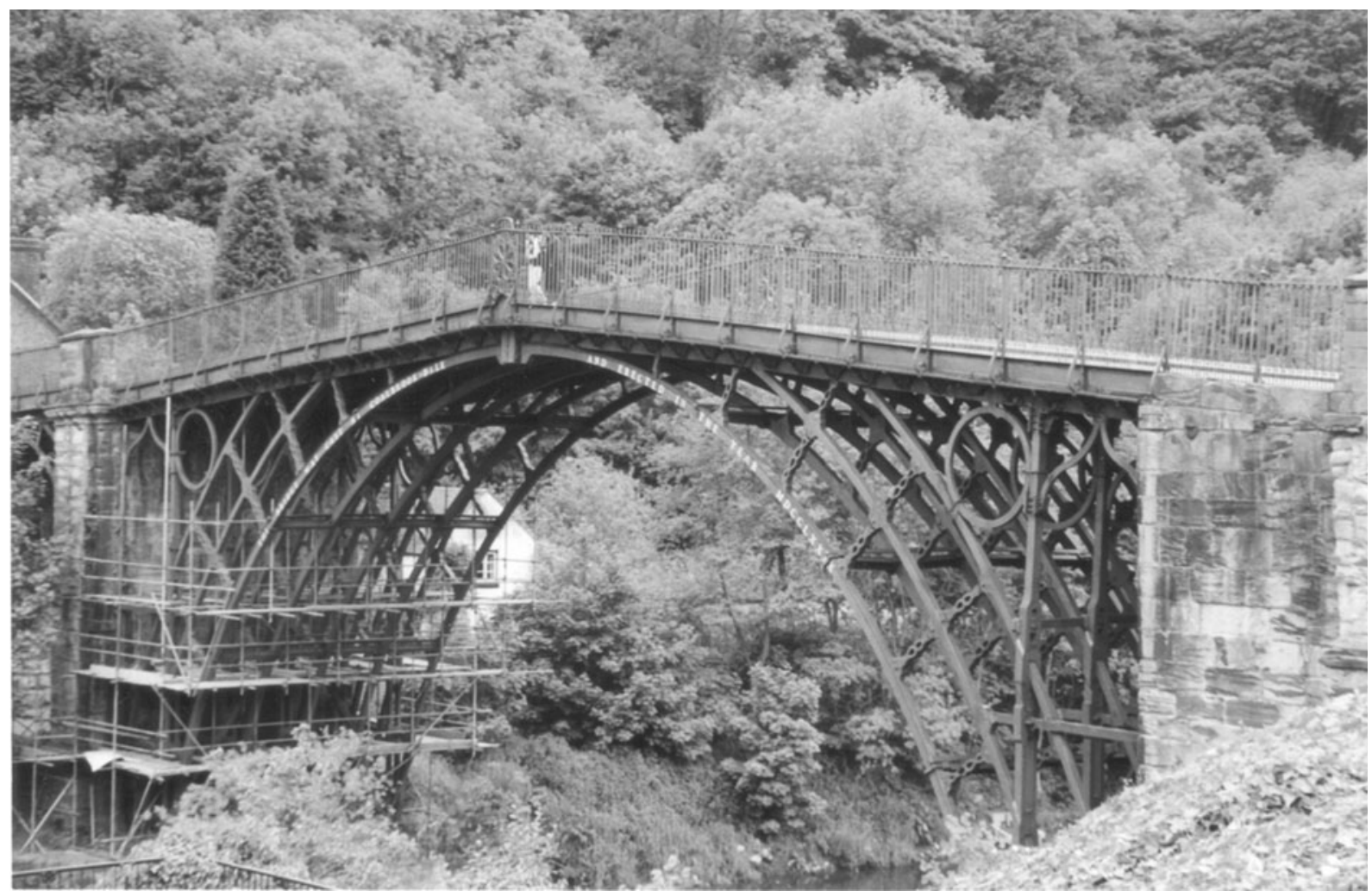

The Ironbridge at Coalbrookdale, England. Photograph by George Krauss

and iron. It shows a complete range of the industrial, social, domestic, and business life of a typical community based upon the principal industry-ironmaking. The industrial monuments include blast furnaces, a brick and tile works, and an inclined plane that carried barges from the top canal to the lower one at Coalport.

In 1986, the Ironbridge Gorge became one of the first sites in the United Kingdom to be awarded World Heritage status by UNESCO. The designation of the Ironbridge Gorge as a World Heritage Site recognized the area's unique contribution to the birth of the Industrial Revolution in the eighteenth century, the impact of which was felt across the world. It was the achievements of pioneering industrialists including Abraham Darby, William Reynolds, and John Wilkinson that led to the Ironbridge Gorge becoming by the close of the eighteenth century the most technologically advanced area in the world.

The Ironbridge was built not only to allow raw materials and people to get from one side of the river to the other but also to demonstrate to the world at large that cast iron could be used as a structural material. Closed to road traffic in 1934, it has since been fully restored and stands proudly at the heart of the Ironbridge Gorge World Heritage Site. The former tollhouse on the south side houses a Tourist Information Centre, as well as displays giving the full history of the bridge that has been rightfully described as the "Symbol of the Industrial Revolution."

"This is really Mohammed's tomb as far as the industrial world is concerned," said Mark Harwood-Little, the Trust's director, "for out of this came iron to build an Empire."

The ASM Historical Landmark award was presented by Donald J. Blickwede, ASM President at the time, and Allan Ray Putnam, then ASM senior managing director, at dedication ceremonies in May 1984. The citation on the award plaque reads: "The first iron bridge, cast of iron smelted with coke, erected in 1799, symbolizes pioneering metallurgical accomplishments, leading to Britain's renown for engineering and manufacturing innovations."

Dr. Blickwede said, "We have a special opportunity to honor the first of the firsts, that accomplishment which preceded everything we have attained in metalworking since the Industrial Revolution. We will never forget that all of today's turbojets, alloy steels, and other metal and materials advances came about because an enterprising Englishman substituted coke for charcoal nearly three centuries ago and began the modern age of metals."

Acknowledgments Information in this article has been adapted from "Three ASM Historical Landmark awards presented," by Kevin J. Bouffard, ASM News, August 1984. For additional information about the Ironbridge Gorge Museums, see http://www.ironbridge. org.uk/. 